\title{
Pertumbuhan dan Produktivitas 5 Varietas Unggul Baru Padi di Lahan Bukaan Baru Kabupaten Boven Digoel
}

\section{Growth and Productivity of 5 New Superior Varieties on New Wetlands Field In Boven Digoel Regency}

\author{
Fajriyatus Shoidah*, Adnan \\ Agricultural Technology Research Center Papua, Jayapura, Papua, Indonesia \\ *Corresponding author. fajriyatus.s@gmail.com
}

Received: September 05, 2020; Accepted: March 27, 2021; Published: April 1, 2021

\begin{abstract}
New wetlands field generally has low productivity, so a technology is needed for improve productivity. New Superior Variety (NSV) is a technology that is considered easy to be adopted by farmers, so knowing a NSV that is able to adapt to the characteristics and conditions of new wetlands field is a must. The study of adaptive NSV on new wetlands field in Boven Digoel Regency is still limited so that the NSV recommendation for farmers is also still limited. The purpose of this study was to examine the growth and production of new superior varieties on the new wetlands fields in Boven Digoel Regency. The study was conducted on new wetlands in Asiki Village, Jair District during AprilAugust 2019. Randomized Complete Block Design was employed with 3 replications using Inpari 36, Inpari 37, Inpago Rindang 1, Inpago Rindang 2 dan Inpara 8. The results showed different varieties perform different agronomy characters observed (plant height, number of tillers, panicle length, number of grains per panicle, filled grain, per panicle, empty grain per panicle and 1000 grain weight). Inpari 37 produced 5.3 ton/ha Dried Unhulled Rice, the highest production compared to other varieties, so that it could potentially be developed in Boven Digoel's new wetlands field. Productivity may still be increased by improving soil fertility conditions.
\end{abstract}

Key words: adaptation; inpari; jajar legowo; papua; performance

Cite this as: Shoidah, F. \& Adnan. (2020). Pertumbuhan dan produktivitas 5 varietas unggul baru padi di lahan bukaan baru Kabupaten Boven Digoel. Agrosains : Jurnal Penelitian Agronomi, 23(1), 6-12. DOI: http://dx.doi.org/10.20961/agsjpa.v23i1.44200

\section{PENDAHULUAN}

Peningkatan produksi padi sawah dapat dilakukan melalui intensifikasi dan ekstensifikasi. Ekstensifikasi pertanian berupa perluasan areal tanam perlu dilakukan sebagai upaya peningkatan produksi jangka panjang karena tingginya laju alih fungsi lahan pertanian ke non pertanian. Perluasan areal berupa pembukaan lahan baru, selain meningkatkan produksi juga meningkatkan luas panen. Boven Digoel merupakan daerah dengan potensi pengembangan lahan pertanian yang tinggi. Alokasi lahan untuk pengembangan pertanian tanaman pangan berdasarkan evaluasi kesesuaian lahan adalah 36,227 ha (Keratorop et al., 2016). Namun, pemanfaatan untuk pertanian baru mencapai 48 ha untuk sawah irigasi dan 140 ha untuk sawah non irigasi (BPS, 2018).

Sawah yang baru dicetak sering dihadapkan pada berbagai permasalahan kesuburan tanah, sehingga produktivitas lahan lebih rendah dibandingkan dengan sawah yang telah mapan. Kendala pada sawah bukaan baru adalah kekahatan unsur fosfat, kemasaman air dan tanah, keracunan Fe dan Al serta bahan organik yang rendah. Keracunan besi untuk budidaya padi pada lahan bukaan baru dapat dikendalikan dengan perbaikan lingkungan tumbuh, seperti pengendalian drainase dan pencucian, ameliorasi dan pemupukan, serta penanaman varietas yang sesuai (Deng et al., 2021; Prasetyo et al., 2006).

Sawah bukaan baru yang memiliki Fe tinggi dan belum memiliki lapisan tapak bajak, memerlukan sistem pengelolaan air yang baik seperti penentuan tinggi genangan serta interval penggenangan-pengeringan (Ishfaq et al., 2020; Prasetyo et al., 2006). Teknis budidaya padi pada lahan bukaan baru dengan melakukan penambahan pupuk NPK berdasarkan uji tanah, pemberian amelioran (dolomit, kapur) dan bahan organik (kompos jerami, POC), pengelolaan air, serta penggunaan varietas adaptif dapat meningkatkan produktivitas lahan (Herviyanti \& Asmar, 2005; Syafruddin et al., 2020; Widowati \& Rochayati, 2008).

Varietas unggul baru memiliki peran penting dalam peningkatan produksi dan merupakan teknologi yang dinilai mudah diadopsi oleh petani. VUB Inpari 36, Inpari 37, Inpago Rindang 1, Inpago Rindang 2 dan Inpara 8 yang diteliti diharapkan dapat menjadi opsi-opsi varietas yang dapat dibudidayakan dan dikembangkan dengan berbagai keunggulan-keunggulan yang dimiliki seperti rasa nasi enak dan disukai, produktivitas tinggi, berumur genjah, serta lebih tahan terhadap hama dan penyakit di lahan bukaan baru Boven Digoel selain varietas-varietas yang telah ada dan telah lama ditanam oleh petani.

Setiap varietas padi memiliki daya adaptasi yang 
berbeda sehingga perlu dilakukan pengkajian daya adaptasi suatu varietas pada lokasi tertentu. Tanaman dengan keragaan agronomis baik dan hasil produksi tinggi merupakan indikator daya adaptasi varietas pada suatu lingkungan. Oleh sebab itu, penelitian ini dilakukan untuk melihat kesesuaian kelima VUB untuk dikembangkan di Kabupaten Boven Digoel. Hasil-hasil penelitian terdahulu terkait VUB memperoleh hasil antara lain produktivitas VUB Inpari 33 di lahan tadah hujan Nimbokrang, Jayapura sebesar 5,9 ton/ha (Beding \& Tiro, 2019). VUB Inpara 2 dan Inpara 4 potensial dikembangkan di rawa pasang surut Merauke (Kasim et al., 2020). Selain itu, VUB Inpara 1-5 beradaptasi baik di lahan rawa lebak bukaan baru Merauke dengan produksi rata-rata 3,2-4,2 ton/ha Gabah Kering Panen/GKP (Djufry \& Kasim, 2015), VUB Inpari 28 dapat dipanen pada umur 143 hari setelah tanam dengan produksi 4,94 ton/ha pada lahan di dataran tinggi Jayawjaya (Kasim et al., 2020).

Adapun sektor pertanian mempunyai kontribusi penting terhadap perekonomian Kabupaten Boven Digoel. Sektor ini berperan penting dalam penyediaan kebutuhan pangan masyarakat termasuk sebagai daerah penghasil beras di Provinsi Papua. Pada saat ini, pengkajian varietas unggul baru padi adaptif pada lahan sawah bukaan baru masih terbatas dilakukan di Kabupaten Boven Digoel sehingga hasil kajian ini diharapkan menghasilkan rekomendasi varietas padi yang adaptif di lahan bukaan baru Boven Digoel. Tujuan penelitian ini adalah untuk mengetahui pertumbuhan dan produksi beberapa varietas padi dan mendapatkan varietas adaptif di lahan bukaan baru Boven Digoel.

\section{BAHAN DAN METODE}

Pengkajian dilaksanakan di Kampung Asiki, Distrik Jair, Kabupaten Boven Digoel. Lahan berada pada ketinggian $28 \mathrm{~m}$ dpl dengan koordinat 6.635197,140.419110. Kegiatan pengkajian dilakukan pada bulan April-Agustus 2019. Pengkajian dilaksanakan di lahan bukaan baru seluas 2 ha yang dimiliki oleh kelompok tani di Kampung Asiki, Distrik Jair, Kabupaten Boven Digoel. VUB Padi yang diujicobakan adalah Inpari 36 (kelas ES), Inpari 37 (kelas ES), Inpago Rindang 1 (kelas FS), Inpago Rindang 2 (kelas FS) dan Inpara 8 (kelas ES). Kajian menggunakan Rancangan Acak Kelompok dengan 3 ulangan sebagai blok. Jarak tanam menggunakan metode jajar legowo 2:1 (25 cm x $12,5 \mathrm{~cm} \times 50 \mathrm{~cm}$ ). Ukuran per petak percobaan adalah adalah $3 \mathrm{~m} \times 4 \mathrm{~m}$.

Pemupukan dilakukan berdasarkan uji cepat menggunakan Perangkat Uji Tanah Sawah (PUTS). Pemupukan dilakukan dua tahap dengan waktu dan dosis pemupukan (Tabel 2). Pemupukan I pada umur tanaman 10-14 HST dan Pemupukan II pada umur tanaman 25-30 HST untuk varietas Inpari 36 dan Inpari 37; Pemupukan I pada umur tanaman 21-25 HST dan Pemupukan II pada umur tanaman 45-50 HST untuk Inpago Rindang 1 dan Inpago Rindang 2; Pemupukan I pada umur tanaman 10-14 HST dan Pemupukan II umur tanaman 45-50 HST untuk varietas Inpara 8. Sampel tanah selanjutnya dianalisis di Laboratorium Penguji Balai Penelitian Tanah Balitbangtan Kementan (Akreditasi KAN: LP-846-IDN). Pengendalian gulma dilakukan menggunakan herbisida saat proses pengolahan lahan, dan pengendalian hama penyakit menggunakan pestisida sesuai dengan instensitas dan jenis serangga.

Pengamatan vegetatif dilakukan pada $60 \mathrm{HST}$ dengan sampel yang diambil sebanyak 5 rumpun tanaman pada setiap ulangan. Pengamatan vegetatif meliputi parameter tinggi tanaman dan jumlah anakan. Panen dilakukan pada usia tanaman 17 MST, kemudian dilakukan pengamatan komponen produksi dengan parameter yang diamati meliputi panjang malai, gabah isi, gabah hampa, total gabah. Produktivitas diukur berdasarkan teknik pengubinan berukuran $2 \times 2.5 \mathrm{~m}$. Data yang diperoleh dianalisis menggunakan analisis ragam dengan uji $\mathrm{F}$ pada taraf $5 \%$. Uji lanjut dengan uji BNT (Beda Nyata Terkecil) pada taraf 5\%.

\section{HASIL DAN PEMBAHASAN \\ Pertumbuhan Tanaman}

Pengamatan vegetatif dilakukan pada $60 \mathrm{HST}$, meliputi parameter tinggi tanaman dan jumlah anakan. Hasil sidik ragam menunjukkan varietas sangat mempengaruhi perbedaan tinggi pada tanaman padi (Tabel 1). Varietas Inpago memiliki tinggi tanaman lebih besar daripada Inpari dan Inpara. Nilai tinggi tanaman paling besar ditunjukkan oleh padi Inpago Rindang 2 sebesar 128,9 cm (Tabel 1). Hal ini sejalan dengan deskripsi VUB padi yang menerangkan bahwa Inpago Rindang lebih tinggi dibanding Inpari dan Inpara. Tinggi tanaman padi mempengaruhi tingkat rebah tanaman.

Tabel 1. Pertumbuhan Berbagai Varietas Tanaman Padi

\begin{tabular}{cccc} 
Varietas & $\begin{array}{c}\text { Tinggi } \\
\text { Tanaman }\end{array}$ & $\begin{array}{c}\text { Jumlah } \\
\text { Anakan }\end{array}$ & $\begin{array}{c}\text { Jumlah } \\
\text { Malai }\end{array}$ \\
\hline Inpari 36 & $88,9 \mathrm{c}$ & $9,0 \mathrm{a}$ & $23,7 \mathrm{c}$ \\
Inpari 37 & $87,7 \mathrm{c}$ & $8,5 \mathrm{ab}$ & $24,7 \mathrm{~b}$ \\
Inpara 8 & $80,2 \mathrm{c}$ & $8,3 \mathrm{~b}$ & $24,1 \mathrm{bc}$ \\
Inpago & $118,9 \mathrm{~b}$ & $3,4 \mathrm{c}$ & $27,1 \mathrm{a}$ \\
Rindang 1 & & & \\
Inpago & $128,9 \mathrm{a}$ & $3,2 \mathrm{c}$ & $26,9 \mathrm{a}$ \\
Rindang 2 & &
\end{tabular}

Keterangan: Angka pada kolom yang sama yang diikuti oleh huruf yang sama menunjukkan tidak berbeda nyata menurut uji BNT pada taraf $5 \%$

Berdasarkan Rice Standard Evaluation System, tinggi tanaman padi dataran rendah dikelompokkan menjadi tiga kriteria yaitu agak pendek $(<110 \mathrm{~cm})$, sedang $(110-130 \mathrm{~cm})$, dan tinggi $(>130 \mathrm{~cm})$, sehingga berdasarkan karakter VUB padi (Tabel 1) diketahui bahwa Inpara 8 termasuk padi agak pendek; Inpari 36, Inpari 37 dan Inpago Rindang 1 termasuk padi sedang, dan Inpago Rindang 2 termasuk padi tinggi. Varietas tipe baru padi baru diharapkan memiliki tinggi $90-100 \mathrm{~cm}$ (Kuzmanović et al., 2021).

Tanaman yang pendek merupakan salah satu penciri varietas padi modern dan berhubungan dengan ketahanan tanaman terhadap rebah dan efisiensi partisi biomassa antara gabah dan jerami. Peningkatan produksi biomassa berkontribusi pada peningkatan potensi hasil padi (Kuzmanović et al., 2021; Lal et al., 2017). Rebah pada tanaman padi menyebabkan kerugian panen. Rebah yang terjadi menjelang panen menurunkan produksi $10-20 \%$, sedangkan rebah yang terjadi pada awal pengisian biji menurunkan produksi mencapai $50-60 \%$ dengan presentase butir kapur mencapai $60 \%$ yang menyebabkan rendahnya komposisi beras kepala. Secara umum rebah meningkatkan gabah hampa dan menurunkan bobot 1000 butir (Dulbari et al., 2018).

Jumlah anakan pada analisis sidik ragam 
menunjukkan perbedaan nilai berdasarkan pengaruh faktor varietas padi (Tabel 1). Berbanding terbalik dengan tinggi tanaman, jumlah anakan Inpari lebih besar daripada Inpago. Inpari 36 mempunyai jumlah anak terbanyak ( 9 anakan) dan berbeda nyata dengan varietas lain kecuali Inpari 37 (8,5 anakan) (Tabel 1). Tinggi tanaman berkorelasi negatif dan kuat terhadap jumlah anakan padi (Tabel 3), dimana diketahui bahwa Giberelin memiliki pengaruh terhadap MOC1 (regulator jumlah anakan) dan SLR1 (protein pemanjangan batang) (Liao et al., 2019).

Meskipun secara genetik varietas tanaman akan menentukan jumlah anakan, namun anakan padi juga merupakan indikator kesehatan tanaman padi. Jumlah anakan akan mengalami penurunan pada fase primordia dan merupakan karakter yang tepat untuk menentukan jarak tanam. Jumlah anakan produktif padi sawah dapat digolongkan menjadi lima, yaitu sangat sedikit (<5 anakan/tanaman), sedikit (5-9 anakan/tanaman), sedang (10-19 anakan/tanaman), ideal (20-25 anakan/tanaman), dan sangat banyak (>25 anakan/tanaman) (Nahar et al., 2018). Anakan merupakan salah satu peubah potensi hasil pada tanaman padi, diketahui bahwa transporter nitrat padi OsNPF7.2 dapat meningkatkan jumlah anakan dan hasil gabah (Wang et al., 2018).

Varietas unggul baru (VUB) adalah kelompok tanaman padi yang memiliki karakteristik umur berkisar 100-135 hari setelah sebar (HSS), anakan banyak (> 20 tunas/rumpun), dan bermalai agak lebat (150 butir gabah/malai) (Santosa et al., 2020). Padi sawah tadah hujan harus memiliki toleransi pada kekeringan, dan memiliki karakteristik potensi hasil tinggi; tinggi tanaman sedang (90-125 cm), batang yang kokoh, posisi daun tegak sampai agak tegak, jumlah anakan produktif yang sedang sampai banyak (10-25 anakan produktif), malai lebat dengan bulir yang banyak (150-250 butir per malai), dan eksersi malai yang baik (skor 7-9) (Saleh \& Suherman, 2021).

Tabel 2. Produksi Berbagai Varietas Tanaman Padi

\begin{tabular}{ccccccc}
\hline Varietas & $\begin{array}{c}\text { Gabah } \\
\text { Isi }\end{array}$ & $\begin{array}{c}\text { Gabah } \\
\text { Hampa }\end{array}$ & $\begin{array}{c}\text { Total } \\
\text { Gabah }\end{array}$ & $\begin{array}{c}\text { Gabah } \\
\text { Bernas (\%) }\end{array}$ & $\begin{array}{c}\text { Bobot } \\
1000 \text { butir }\end{array}$ & $\begin{array}{c}\text { Produksi } \\
\text { (ton/ha) }\end{array}$ \\
\hline Inpari 36 & $123,0 \mathrm{~b}$ & $17,6 \mathrm{c}$ & $140,6 \mathrm{~b}$ & 87,48 & $29,3 \mathrm{~d}$ & $4,7 \mathrm{ab}$ \\
Inpari 37 & $125,7 \mathrm{~b}$ & $21,3 \mathrm{c}$ & $147,0 \mathrm{~b}$ & 85,51 & $28,0 \mathrm{e}$ & $5,3 \mathrm{a}$ \\
Inpara 8 & $146,0 \mathrm{a}$ & $30,1 \mathrm{~b}$ & $176,2 \mathrm{a}$ & 82,86 & $30,3 \mathrm{c}$ & $4,2 \mathrm{bc}$ \\
Inpago Rindang 1 & $125,2 \mathrm{~b}$ & $50,5 \mathrm{a}$ & $175,7 \mathrm{a}$ & 71,26 & $36,0 \mathrm{~b}$ & $3,7 \mathrm{c}$ \\
Inpago Rindang 2 & $129,7 \mathrm{~b}$ & $46,1 \mathrm{a}$ & $175,8 \mathrm{a}$ & 78,78 & $37,0 \mathrm{a}$ & $2,3 \mathrm{~d}$ \\
\hline
\end{tabular}

Keterangan: Angka pada kolom yang sama yang diikuti oleh huruf yang sama menunjukkan tidak berbeda nyata menurut uji BNT pada taraf $5 \%$

Kehampaan gabah dapat disebabkan faktor genetik maupun non genetik (Sukristiyonubowo et al., 2019). Persentase gabah hampa dipengaruhi oleh lama penyinaran dan intensitas cahaya yang rendah, dan dipengaruhi oleh kemampuan tanaman dalam menyerap hara dan intensitas serangan hama dan penyakit (Rusdiansyah et al., 2015). Salah satu penyebab kehampaan adalah tidak seimbangnya sink dan source; jumlah anakan (sink) yang banyak tidak didukung oleh sumber daya hara (source) yang memadai, atau jumlah gabah per malai (sink) banyak, tetapi sumber hara (source) kurang mendukung. Kerapatan malai yang tinggi dapat menyebabkan persentase gabah hampa pada malai lebih besar. Karakter lain tanaman seperti daun yang tipis, mendatar dan cepat luruh, serta tanaman yang berumur genjah

\section{Produksi}

Perbedaan varietas yang ditanam menunjukkan pengaruh yang berbeda pada parameter panjang malai (Tabel 1). Panjang malai tertinggi terdapat pada varietas Inpago Rindang $1(27,1 \mathrm{~cm})$ dan tidak berbeda nyata dengan Inpago Rindang $2(26,9 \mathrm{~cm})$, sedangkan panjang malai terendah terdapat pada varietas Inpari 36 $(23,7 \mathrm{~cm})$ (Tabel 1). Panjang malai akan berpengaruh terhadap jumlah gabah total per malai. Hal ini sesuai dengan pernyataan H \& Idwar, (2015) bahwa malai yang panjang akan meningkatkan jumlah hasil gabah. banyaknya hasil karena setiap bertambahnya panjang malai maka akan tumbuh cabang-cabang tangkai gabah yang menghasilkan gabah yang lebih banyak. Akbar et al., (2019) juga menjelaskan bahwa pada padi sawah tadah hujan dihaploid, panjang malai memiliki korelasi positif yang kuat dengan jumlah gabah total per malai, dan memiliki pengaruh tidak langsung terhadap hasil.

Variabel varietas pada analisis sidik ragam menunjukkan pengaruh yang berbeda pada parameter jumlah gabah isi per malai, gabah hampa per malai, dan total gabah per malai (Tabel 2). Inpara 8 memiliki gabah isi tertinggi (146 butir) dan berbeda nyata dengan varietas lainnya, sedangkan Inpari 36 menghasilkan gabah isi terendah (123 butir). Gabah hampa tertinggi terdapat pada varietas Inpago Rindang 1 (50,5 butir) dan tidak berbeda nyata dengan Inpago Rindang $2(46,1$ butir), sedangkan gabah hampa terendah terdapat pada Inpari 36 (17,6 butir). Total gabah tertinggi terdapat pada varietas Inpara 8 (176,2 butir) dan tidak berbeda nyata dengan Inpago Rindang 1 (175,7 butir) dan Inpago Rindang 2 (175,8 butir), sedangkan total gabah terendah terdapat pada Inpari 36 (140,6 butir). Persentase gabah bernas tertinggi ditunjukkan oleh varietas Inpari $36(87,48 \%)$, diikuti oleh Inpari 37 $(85,51 \%)$, Inpara 8 (82,86\%), Inpago Rindang 2 (78,78\%) dan Inpagi Rindang 1 (71,26\%) (Tabel 2). Peningkatan panjang malai akan mempengarui menyebabkan asimilat yang dihasilkan rendah dan kurang mencukupi untuk pengisian gabah (Widyaningtias et al., 2020).

Analisis sidik ragam menunjukkan bobot 1000 butir dipengaruhi oleh variabel varietas (Tabel 2). Bobot tertinggi terdapat pada varietas Inpago Rindang 2 (37 g) dan berbeda nyata dengan varietas lain, sedangkan bobot terendah terdapat pada varietas Inpari 37 (28 g) (Tabel 2). Bobot gabah 1000 butir ditentukan oleh bentuk gabah dan pengisian bulir yaitu kondisi sebelum, saat, dan setelah terjadinya pembungaan, seperti ketersediaan air dan kondisi cuaca. Gabah yang lonjong dan penuh akan cenderung memiliki bobot 1000 butir lebih berat dibandingkan ukuran gabah yang bulat. Secara umum, padi mempunyai bobot 1000 butir gabah sebesar 25-27 g (Chandio et al., 2020; Chen et al., 2020; 
Fei et al., 2020). Varietas padi sangat mempengaruhi produktivitas (Tabel 3 ), dimana produktivitas tertinggi terdapat pada varietas Inpari 37 (5,3 ton/ha) yang berbeda nyata dengan varietas lainnya, sedangkan produktivitas terendah terdapat pada varietas Inpago Rindang 2 (2,3 ton/ha) (Tabel 2).

Produksi berkorelasi positif dan kuat terhadap jumlah anakan, namun memiliki korelasi negatif dan kuat terhadap bobot 1000 butir, gabah hampa, jumlah gabah, panjang malai dan tinggi tanaman. Korelasi negatif dan bersifat lemah pada produktivitas sebaliknya ditunjukkan oleh parameter gabah isi (Tabel 3). Hasil korelasi tersebut menunjukkan bahwa varietas yang memiliki lebih banyak jumlah anakan tetapi memiliki bobot 1000 butir, gabah hampa, jumlah gabah, panjang malai dan tinggi tanaman yang lebih rendah daripada varietas lain menghasilkan produktivitas yang lebih tinggi.

Tabel 3. Nilai Koefisien Korelasi Antar Karakter Agronomi yang Diamati Pada VUB Padi

\begin{tabular}{|c|c|c|c|c|c|c|c|}
\hline & BSB & $\mathrm{GH}$ & Gl & JA & $J G$ & PM & PRD \\
\hline $\mathrm{GH}$ & $0,95^{*}$ & & & & & & \\
\hline Gl & $-0,08$ & 0,04 & & & & & \\
\hline JA & $-0,98^{* *}$ & $-0,96^{* *}$ & 0,17 & & & & \\
\hline$J G$ & 0,75 & 0,85 & 0,56 & $-0,71$ & & & \\
\hline PM & $0,92^{*}$ & $0,94^{*}$ & $-0,25$ & $-0,98^{* *}$ & 0,65 & & \\
\hline PRD & $-0,92^{*}$ & $-0,81$ & $-0,13$ & 0,85 & $-0,74$ & $-0,74$ & \\
\hline TT & $0,94^{*}$ & 0,86 & $-0,36$ & $-0,96^{* *}$ & 0,52 & $0,94^{*}$ & $-0,84$ \\
\hline
\end{tabular}

Keterangan: BSB= Bobot 1000 Butir, GH= Gabah Hampa, GI= Gabah Isi, JA= Jumlah Anakan, JB= Jumlah Gabh, PM= Panjang Malai, PRD= Produktivitas, TT= Tinggi Tanaman, ${ }^{* *}=$ berkorelasi nyata pada $\alpha 0.01,{ }^{*}=$ berkorelasi nyata pada $\alpha 0.05$

Karakter yang harus dimiliki untuk calon suatu varietas diantaranya, yaitu umur panen (hari), tinggi, anakan produktif, jumlah gabah per malai, bobot 1000 butir (g), persentase gabah hampa, dan produktivitas per hektar. Karakter varietas unggul baru (VUB) diantaranya umur berkisar 100-135 hari setelah sebar (HSS), anakan banyak (> 20 tunas/rumpun), dan bermalai agak lebat (150-250 butir gabah/malai) dengan tingkat pengisian $85-95 \%$ sehingga memiliki potensi hasil tinggi (>9 ton/ha) (Lestari et al., 2020; Phapumma et al., 2020).

Tabel 4. Perbandingan Komponen Pertumbuhan dan Produksi Inpari 37

\begin{tabular}{ccc}
\hline Parameter & Hasil & Referensi $^{*}$ \\
\hline Tinggi Tanaman (cm) & 87,7 & 111,0 \\
Jumlah Anakan (anakan) & 8,5 & 16,0 \\
Bobot 1000 butir (g) & 28,0 & 25,0 \\
Produksi (ton/ha) GKP & 5,3 & $7,3^{* \star}$ \\
\hline
\end{tabular}

Keterangan: ${ }^{\star}$ Deskripsi Varietas BB Padi; ${ }^{* *}$ konversi dari 6.3 ton/ha GKG

Hasil kajian menunjukkan bahwa Inpari 37 sesuai dengan kondisi agroklimat Kabupaten Boven Digoel. Varietas tersebut dapat beradaptasi dengan baik pada kondisi spesifik lokasi sehingga memberikan hasil 5,3 ton/ha GKP, lebih tinggi dibandingkan varietas lain (Tabel 2). Teknologi inovasi Balitbangtan BPTP Papua dalam bentuk introduksi VUB dan jarak tanam jajar legowo serta pemupukan sesuai rekomendasi memberikan produktivitas lebih tinggi daripada hasil yang diperoleh petani dengan rata-rata produktivitas 4,2 ton/ha GKP. Namun, hasil Inpari 37 di Boven Digoel masih bisa ditingkatkan agar setara dengan rata-rata produktivitas nasional Inpari 37 sebesar 7,3 ton/ha GKP (Tabel 4). Sistem tanam jajar legowo secara signifikan memiliki hasil panen lebih tinggi dibanding sistem tanam tegel atau eksisting petani (Susanto et al., 2020; Syafruddin et al., 2020).

\section{Karakteristik Lahan Bukaan Baru Boven Digoel}

Secara umum, kondisi kesuburan lahan di lokasi demplot tergolong rendah (Tabel 5). Tekstur tanah lempung liat berdebu dengan kondisi masam serta unsur hara makro dan mikro cenderung rendah. Peningkatan produktivitas padi masih bisa dimungkinkan dengan perbaikan kondisi kesuburan lahan serta pemupukan sesuai rekomendasi. Lahan sawah bukaan baru umumnya dicetak pada lahan basah dan lahan kering. Sawah yang baru dicetak sering dihadapkan pada berbagai permasalahan kesuburan tanah, sehingga produktivitas lahan lebih rendah dibandingkan dengan sawah yang telah mapan. Kendala pada sawah bukaan baru adalah kekahatan unsur fosfat, kemasaman air dan tanah, keracunan Fe dan Al serta bahan organik yang rendah. Keracunan besi untuk budidaya padi pada lahan bukaan baru dapat dikendalikan dengan perbaikan lingkungan tumbuh; pengendalian drainase dan pencucian, ameliorasi dan pemupukan, serta penanaman varietas yang sesuai (Diop et al., 2020; Tin, Loi, Bjornstad, et al., 2017). Sawah bukaan baru yang memiliki Fe tinggi dan belum memiliki lapisan tapak bajak, memerlukan sistem pengelolaan yang baik seperti tingkat dan intensitas penggenangan, serta intensitas pengeringan (Tin, Loi, Labarosa, et al., 2017).

Sistem pengairan yang baik, pemupukan secara terpadu antara pupuk kimia dan pupuk organik dan penggunaan varieas adaptif dapat meningkatkan produktivitas dan efisiensi usahatani padi serta dapat mengurangi penggunaan pupuk kimia dan air irigasi, baik pada lahan sawah intensif maupun suboptimal (Turmuktini et al., 2012; Wahid \& Sirappa, 2013). Pada sawah bukaan baru, budidaya padi dengan melakukan penambahan pupuk NPK berdasarkan uji tanah, pemberian amelioran (dolomit, kapur) dan bahan organik (kompos jerami, POC), pengelolaan air, serta penggunaan varietas adaptif dapat meningkatkan produktivitas lahan (Herviyanti \& Asmar, 2005; Sahardi et al., 2014; Sukristiyonubowo et al., 2019; Syafruddin et al., 2020; Widowati \& Rochayati, 2008) 
Tabel 5. Analisis Tanah

\begin{tabular}{|c|c|c|c|}
\hline \multicolumn{2}{|c|}{ Parameter } & Nilai & Kriteria \\
\hline \multirow{3}{*}{ Tekstur } & Pasir (\%) & 6 & \\
\hline & Debu (\%) & 64 & Lempung Liat Berdebu \\
\hline & Liat (\%) & 30 & \\
\hline \multirow{2}{*}{$\mathrm{pH}$} & $\mathrm{H} 2 \mathrm{O}$ & 5,0 & Masam \\
\hline & $\mathrm{KCl}$ & 3,7 & \\
\hline \multicolumn{2}{|c|}{ Salinitas $(\mathrm{mg} / \mathrm{l})$} & 10 & \\
\hline \multicolumn{2}{|c|}{$\mathrm{DHL}(\mathrm{dS} / \mathrm{m})$} & 0,020 & Sangat Rendah \\
\hline \multirow{3}{*}{ Bahan Organik } & Walkley \& Black C (\%) & 1,67 & Rendah \\
\hline & Kjeldahl N (\%) & 0,21 & Sedang \\
\hline & $\mathrm{C} / \mathrm{N}$ & 8 & Rendah \\
\hline \multicolumn{2}{|c|}{ Bray $1 \mathrm{P}_{2} \mathrm{O}_{5}(\mathrm{ppm})$} & 1,1 & Rendah \\
\hline \multicolumn{2}{|c|}{ Morgan $\mathrm{K}_{2} \mathrm{O}(\mathrm{ppm})$} & 26 & Sedang \\
\hline \multirow{7}{*}{ Nilai Tukar Kation } & $\mathrm{Ca}(\mathrm{cmol} / \mathrm{kg})$ & 1,23 & Sangat Rendah \\
\hline & $\mathrm{Mg}(\mathrm{cmol} / \mathrm{kg})$ & 0,41 & Rendah \\
\hline & $\mathrm{K}(\mathrm{cmol} / \mathrm{kg})$ & 0,04 & Sangat Rendah \\
\hline & $\mathrm{Na}(\mathrm{cmol} / \mathrm{kg})$ & 0,05 & Sangat Rendah \\
\hline & Jumlah (cmol/kg) & 1,73 & \\
\hline & KTK (cmol/kg) & 8,73 & Rendah \\
\hline & KB (\%) & 20 & Rendah \\
\hline \multirow{2}{*}{\multicolumn{2}{|c|}{$\begin{array}{c}\mathrm{Al}^{3+}(\mathrm{cmol} / \mathrm{kg}) \\
\mathrm{H}^{+}(\mathrm{cmol} / \mathrm{kg})\end{array}$}} & 2,83 & \\
\hline & & 0,38 & \\
\hline
\end{tabular}

\section{KESIMPULAN}

Perbedaan varietas mempengaruhi perbedaan karakter agronomi yang diamati (tinggi tanaman, jumlah anakan, panjang malai, jumlah gabah per malai, gabah isi per malai, gabah hampa per malai dan bobot 1000 butir). Varietas Inpari 37 menghasilkan produksi tertinggi sebesar 5,3 ton/ha GKP sehingga berpotensi dikembangkan di lahan bukaan baru Boven Digoel.

\section{DAFTAR PUSTAKA}

Akbar, M. R., Purwoko, B. S., Dewi, I. S., Suwarno, W. B., \& Sugiyanta, D. (2019). Penentuan indeks seleksi untuk galur dihaploid padi sawah tadah hujan berdaya hasil tinggi. Jurnal Agronomi Indonesia (Indonesian Journal of Agronomy), 47(2), 111-118. https://doi.org/10.24831/jai.v47i2.25032

Beding, P. A., \& Tiro, B. M. W. (2019). Pengelolaan tanaman terpadu padi varietas unggul baru di lahan sawah tadah hujan di Kabupen Jayapura, Papua. Al Ulum Jurnal Sains Dan Teknologi, 5(1), 18. https://doi.org/10.31602/ajst.v5i1.2471

BPS. (2018). Statistik daerah Kabupaten Boven Digoel tahun 2018

Chandio, A. A., Magsi, H., \& Ozturk, I. (2020). Examining the effects of climate change on rice production: case study of Pakistan. Environmental Science and Pollution Research, 27(8), 7812-7822. https://doi.org/10.1007/s11356-019-07486-9

Chen, X., Wang, L., Niu, Z., Zhang, M., Li, C., \& Li, J. (2020). The effects of projected climate change and extreme climate on maize and rice in the Yangtze River Basin, China. Agricultural and Forest Meteorology, 282-283(December 2019), 107867. https://doi.org/10.1016/j.agrformet.2019.107867

Deng, X., Chen, B., Chen, Y., Lu, L., Yuan, X., Yang, Y., \& Zeng, Q. (2021). Variations in root morphological indices of rice (Oryza sativa $L$.) induced by seedling establishment methods and their relation to arsenic accumulation in plant tissues *. Environmental Pollution, 281, 116999. https://doi.org/10.1016/j.envpol.2021.116999
Diop, B., Wang, D. R., Drame, K. N., Gracen, V., Tongoona, P., Dzidzienyo, D., Nartey, E., Greenberg, A. J., Djiba, S., Danquah, E. Y., \& McCouch, S. R. (2020). Bridging old and new: Diversity and evaluation of high iron-associated stress response of rice cultivated in West Africa. Journal of Experimental Botany, 71(14), 4188-4200. https://doi.org/10.1093/jxb/eraa182

Djufry, F., \& Kasim, A. (2015). Adaptability test on new high yielding varieties of swamp rice planted on newly opened paddy field in the district of Merauke Province of Papua. J. Agrotan, 1(1), 99-109. https://core.ac.uk/download/pdf/326501534.pdf

Dulbari, ., Santosa, E., Agusta, H., Guntoro, D., Zaman, S., \& Koesmaryono, Y. (2018). Production and rice quality of two rice varieties after lodging and flooding. Jurnal IImu Pertanian Indonesia, 23(1), 74-80. https://doi.org/10.18343/jipi.23.1.74

Fei, L., Meijun, Z., Jiaqi, S., Zehui, C., Xiaoli, W., \& Jiuchun, Y. (2020). Maize, wheat and rice production potential changes in China under the background of climate change. Agricultural Systems, 182(April), 102853. https://doi.org/10.1016/j.agsy.2020.102853

H, S., \& Idwar. (2015). Respon berbagai varietas padi sawah (Oryza sativa L.) yang ditanam dengan pendekatan teknik budidaya jajar legowo dan sistem tegel. JOM Faperta, 2(2), 13-18. http://weekly.cnbnews.com/news/article.html?no $=12$ 4000

Herviyanti, \& Asmar. (2005). Potensi senyawa organik tidak ter-ion dalam mengurangi kelarutan besi (fe) untuk meningkatkan produktifitas tanah sawah bukaan baru. Jurnal Solum, 11(1), 40-49.

Ishfaq, M., Akbar, N., Anjum, S. A., \& Anwar-IJL-HAQ, M. (2020). Growth, yield and water productivity of dry direct seeded rice and transplanted aromatic rice under different irrigation management regimes. Journal of Integrative Agriculture, 19(11), 2656-2673. https://doi.org/10.1016/S2095-3119(19)62876-5

Kasim, A., Laksono, P., Rumbarar, M. K., \& Thamrin, M. (2020). Adaptation of new superior rice varieties at 
the altitude of 1600 masl in Jayawijaya Papua. IOP Conference Series: Earth and Environmental Science, 484(1). https://doi.org/10.1088/17551315/484/1/012085

Keratorop, M., Widiatmaka, \& Suwardi. (2016). Arahan pengembangan komoditas unggulan pertanian tanaman pangan di Kabupaten Boven Digoel Provinsi Papua Marianus. Plano Madani, 5(2), 143-157.

Kuzmanović, L., Giovenali, G., Ruggeri, R., Rossini, F., \& Ceoloni, C. (2021). Small "nested" introgressions from wild thinopyrum species, conferring effective resistance to fusarium diseases, positively impact durum wheat yield potential. Plants, 10(3), 1-16. https://doi.org/10.3390/plants10030579

Lal, B., Gautam, P., Panda, B. B., Raja, R., Singh, T., Tripathi, R., Shahid, M., \& Nayak, A. K. (2017). Crop and varietal diversification of rainfed rice based cropping systems for higher productivity and profitability in Eastern India. PLOS ONE, 12(4), 1-23. https://doi.org/10.1371/journal.pone.0175709

Lestari, A. P., Rumanti, I. A., Sitaresmi, T., \& Khairullah, I. (2020). Tidal swamp tolerant rice lines: Climate change adaptive varieties. IOP Conference Series: Earth and Environmental Science, 423(1). https://doi.org/10.1088/1755-1315/423/1/012049

Liao, Z., Yu, H., Duan, J., Yuan, K., Yu, C., Meng, X., Kou, L., Chen, M., Jing, Y., Liu, G., Smith, S. M., \& Li, J. (2019). SLR1 inhibits MOC1 degradation to coordinate tiller number and plant height in rice. Nature Communications, 10(1), 1-9. https://doi.org/10.1038/s41467-019-10667-2

Nahar, S., Vemireddy, L. R., Sahoo, L., \& Tanti, B. (2018). Antioxidant protection mechanisms reveal significant response in drought-induced oxidative stress in some traditional Rice of Assam, India. Rice Science, 25(4), 185-196. https://doi.org/10.1016/j.rsci.2018.06.002

Phapumma, A., Monkham, T., Chankaew, S., Kaewpradit, W., Harakotr, P., \& Sanitchon, J. (2020). Characterization of indigenous upland rice varieties for high yield potential and grain quality characters under rainfed conditions in Thailand. Annals of Agricultural Sciences, 65(2), 179-187. https://doi.org/10.1016/j.aoas.2020.09.004

Prasetyo, T. B., Ruhaimah, \& Wardhana, S. A. (2006). Effect of water management on iron $(\mathrm{Fe})$ concentrations in new open rice fields. Solum Journal, III(1), 8-18.

Rusdiansyah, Subiano, T., \& Saleh, M. (2015). Seleksi lanjut kultivar padi sawah lokal Kalimantan Timur. Agrifor: Jurnal Ilmu Pertanian dan Kehutanan, 14(1), 103-112.

Sahardi, S., Herniwati, H., \& Djufry, F. (2014). Produktivitas tanaman dan kelayakan finansial padi di lahan sawah bukaan baru dengan berbagai pemupukan di Sulawesi Selatan. Jurnal Pengkajian Dan Pengembangan Teknologi Pertanian, 17(3), 163272. https://doi.org/10.21082/jpptp.v17n3.2014.p

Saleh, K., \& Suherman. (2021). Model kapasitas petani padi sawah dalam mendukung ketahanan pangan berkelanjutan di Kabupaten Tangerang. Jurnal Penyuluhan, 17(01), 40-51.
Santosa, E., Agusta, H., Guntoro, D., \& Zaman, S. (2020). Strength assessment of rice hills from different planting distance by loading simulation. IImu Pertanian (Agricultural Science), 5(3), 131-139. https://jurnal.ugm.ac.id/jip

Sukristiyonubowo, S., Riyanto, D., \& Widodo, S. (2019). Kesuburan tanah dan produktivitas padi pada budidaya organik, semi organik, dan konvensional di Kabupaten Sragen. Agrotechnology Research Journal, 3(2), 93. https://doi.org/10.20961/agrotechresj.v3i2.32508

Susanto, U., Barokah, U., \& Ali, J. (2020). Yield of green super rice (GSR) lines under legowo and squared planting system. IOP Conference Series: Earth and Environmental Science, 484(1). https://doi.org/10.1088/1755-1315/484/1/012055

Syafruddin, Damayanti, A. I., Muchtar, Febrianti, T., Saidah, \& Rahayu, H. S. P. (2020). The adaptation of new superior varieties on new rice field in Central Sulawesi. IOP Conference Series: Earth and Environmental Science, 484(1). https://doi.org/10.1088/1755-1315/484/1/012075

Tin, H. Q., Loi, N. H., Bjornstad, Å., Kilian, B., \& Campus, S. (2017). Participatory selection of cwr-derived salttolerant rice lines adapted to the coastal zone of the Mekong Delta Development Research Institute - Can Tho University, Can Tho City, Vietnam Global Crop Diversity Trust - Platz der Vereinten Nat. 1-19. https://doi.org/10.1002/csc2.20405.This

Tin, H. Q., Loi, N. H., Labarosa, S. J. E., Mcnally, K. L., \& Kilian, B. (2017). Assessment of the phenotypic response of $50 \mathrm{CWR}$ - derived rice lines selected by farmers in the Mekong Delta to salt stress at the seedling stage. Crop Science, 1-44. https://doi.org/10.1002/csc2.20354.This

Turmuktini, T., Simarmata, T., Joy, B., \& Resmini, A. C. (2012). Management of water saving and Oorganic based fertilizers technology for remediation and maintaining the health of paddy soils and to increase the sustainability of rice productivity in Indonesia. Asian Economic and Social Society, 2(4), 536-551.

Wahid, \& Sirappa, M. (2013). Potensi budidaya PTT Inpara 1 dan Indragiri lahan sub optimal waeapo, buru potency. Agros, 15(1), 230-241.

Wang, J., Lu, K., Nie, H., Zeng, Q., Wu, B., Qian, J., \& Fang, Z. (2018). Rice nitrate transporter OsNPF7.2 positively regulates tiller number and grain yield. Rice, 11(1), 1-13. https://doi.org/10.1186/s12284018-0205-6

Widowati, L., \& Rochayati, S. (2008). Pengelolaan hara untuk meningkatkan produktivitas lahan sawah bukaan baru di Harapan Masa-Tapin Kalimantan Selatan. Seminar Nasional BBSDLP, 53-64.

Widyaningtias, L. A. M., Yudono, P., \& Supriyanta, S. (2020). Identifikasi karakter morfologi dan agronomi penentu kehampaan malai padi (Oryza sativa L.). Vegetalika, 9(2), 399. https://doi.org/10.22146/veg.50721 